\title{
Editor's message: Fifth World Water Forum in Istanbul, Turkey-a short report and a comment on the representation of groundwater
}

\author{
Gholam A. Kazemi
}

Keywords Editorial · Iran · Turkey

The Fifth World Water Forum was held in Istanbul, Turkey on 16-22 March 2009. This gathering, which is the largest of its kind globally and the most important water-related event, is held once every three years. The previous ones took place in Mexico City (Mexico), Kyoto (Japan), Hague (Netherlands) and Marrakech (Morocco) in 2006, 2003, 2000 and 1997, respectively. The World Water Council (WWC) is the chief body responsible for organizing this forum, though intensive intergovernmental, governmental and non-governmental collaboration, co-operation and involvement is needed to successfully execute such a large event. From the Turkish side, the State Hydraulic Works (DSI) was the organizer of the forum. The fifth forum was held in two separate locations in a beautiful suburb, a couple of hundred meters apart and connected by a bridge; boats were also available to commute between the two sites. Based on the official website of the forum (www.worldwaterforum5.org), there were more than 35,000 participants. However, the author, who attended the first four days of the forum (due to the need to return home for the occasion of Iranian New Year on 21 March), heard that the number of participants ranged from 6,000 to 29,000 . In addition to Turkey's president, the President of Iraq attended the inaugural

Received: 8 April 2009 / Accepted: 19 October 2009

Published online: 11 November 2009

(C) Springer-Verlag 2009

Gholam Abbas Kazemi is an Associate Editor of Hydrogeology Journal.

\section{G. A. Kazemi (}

Faculty of Earth Sciences,

Shahrood University of Technology,

P.O. Box 316

University Boulevard, Shahrood, 36155, Iran

e-mail: g_a_kazemi@shahroodut.ac.ir

e-mail: ga kazemi@hotmail.com

Tel.: +98-273-3336007

Fax: +98-273-3334419 ceremony, as did a number of other dignitaries and high ranking officials. Media coverage of the event was high and newsletters were being published simultaneously to update interested parties. This editor's message intends to briefly report on the forum, albeit from a hydrogeologist's view point, and also to comment on the prominence of 'groundwater' at the forum.

It is a large task to report on a gathering the size of the World Water Forum, which is comparable to the World Economic Forum held in Davos-Klosters, Switzerland every year. However, a brief report could prove useful for those interested readers who were not able to attend. The World Water Forum aims to bring under one roof all the waterrelated stakeholders from the four corners of the world to exchange ideas, to learn from each other, to expose capabilities and opportunities, and to discuss the water issues that challenge the world. In this respect, the author believes that the forum was successful in achieving its goals. One reason is the high number of attendees. This year's motto of the forum was "Bridging Divides for Water", which clearly points to the need for international and national cooperation to meet the water demands of humanity, nature and the environment, while highlighting the fact that water, and especially water scarcity, could be a source of peace, just as it can be a cause of conflict between nations.

The forum consisted of a variety of activities including, among others, six major themes, extensive exhibitions and expos, ministerial meetings, regional processes, high-level expert panels, side events, a children's forum, a youth forum, a learning center and a number of water-related prizes. The general lack of focus of the sessions devoted to the six major themes, in the author's opinion, did not lead to presentations that were as informative as they could have been. Kiosks, expos and open-air activities were especially attractive and effective, allowing participants to utilize every minute of their time spent at the forum. The short courses organized by the Learning Centre of the forum were focused, specific and detailed and were very useful for educational purposes, especially for graduate students and practitioners. The author attended a few of these courses and also presented one.

The author has noted a few points at the forum which he would like to share with the readers of Hydrogeology Journal (HJ). First, the strong emphasis and the level of 
attention that was paid to the recycling of wastewater and development of multi-stage treatment plants to improve the quality of such water for domestic purposes were noticeable. A variety of wastewater treatment plants and treatment techniques were promoted. The rational behind this is that wastewater is present wherever human settlements are present. Therefore, wastewater treatment could be a reliable approach to fight water scarcity. Second, was the issue of desalinization of seawater and the advances that have been made in this field. Through a video presentation, a company promoted a specific custom-made large desalinization plant which can be mounted on ships and carried to any location. This plant takes six months to assemble and can deliver $20,000 \mathrm{~m}^{3}$ of water per day at the cost of 1.4 Euros $/ \mathrm{m}^{3}$ with the initial cost of 20,000,000 Euros. One such plant has been constructed for Cyprus. The third issue is the use and development of dry toilets. The author heard from one attendee that a new toilet system which uses no water is being developed and tested. It was noted that cultural barriers could prevent the use of such a system in Muslim countries like Iran. The fourth issue that grabbed the attention of the author was the conjunctive presentation by the US Geological Survey and US Army Corps of Engineers. While outlining the water resources of Iraq and the sophisticated instrumentation they installed on Iraqi rivers, the presentation also quietly pointed to the disappointing reality concerning the transboundary waters of Iraq and Turkey and the conflict that could arise between these countries in 2020-2025. It should be noted that $70 \%$ of Iraq's surface-water resources issues from the mountains of Turkey, where dams are currently being constructed on some of the headwaters.

Some of the hydrogeologists actively participating at the Fifth World Water Forum have observed that groundwater presence was much more notable at this forum than at previous forums (Campana 2009), which is a very good sign. However, from this author's observations, groundwater was not ideally represented in the early days of the forum. Groundwater-related themes were, for example, placed in the last two days of the forum when a considerable fraction of the attendees had already left and when the activities of the forum started to slow down. Similarly, there was no high-level expert panel to deal with groundwater in the early days of the forum.

Setting up stands and kiosks in such a large forum is a costly activity and has prevented the International Association of Hydrogeologists (IAH) from having a stand of its own at such large events (M. Schafmeister, Hydrogeology Journal, personal communication, June 2009). Overall, at the Fifth Forum, expos, kiosks and stands devoted to groundwater were limited, although there were companies advertising various kinds of pressure transducers and also there were short courses related to qanats and groundwater dating. The number of groundwater specialists appeared to be limited too. This was the case not only at the forum but also at the hotel where the author and the other participants were accommodated. There was consensus amongst these participants that the 'groundwater' turnout was low and its voice was inadequate, despite the fact that a large percentage of world water needs are supplied by groundwater resources. It is also well known that these resources are under threat both quality wise and quantity wise. It is hoped that, at the next World Water Forum meeting, the presence of groundwater and the groundwater community will continue to extend and expand. The author believes that editorials like this can bring the World Water Forum to the attention of hydrogeologists and that this forum is a truly magnificent one that is well worth attending, especially for academia who want to be updated with regard to global water issues.

Acknowledgements The review and comments of C. Voss and M. Schafmeister and technical editing of S. Duncan, all from HJ's editorial board, have helped to improve this manuscript and they are duley thanked for their input.

\section{References}

Campana ME (2009) Reflecting on the Fifth World Water Forum. IAH USNC Newslett 38(2):5-6 